\title{
MECHANISMS AND PRACTICAL CONSIDERATIONS INVOLVED IN PLANT GROWTH PROMOTION BY RHIZOBACTERIA
}

\author{
O. Martínez-Viveros ${ }^{1}$, M.A. Jorquera ${ }^{2}$, D.E. Crowley ${ }^{3}$, G. Gajardo ${ }^{4}$ and \\ M.L. Mora ${ }^{2}$
}

${ }^{1}$ Programa de Doctorado en Ciencias de Recursos Naturales, Universidad de La Frontera, Avenida Francisco Salazar 01145, Temuco, Chile. ${ }^{2}$ Center of Plant, Soil Interaction and Natural Resources Biotechnology, Scientific and Technological Bioresource Nucleus, Universidad de La Frontera, Avenida Francisco Salazar 01145, Temuco, Chile. ${ }^{3}$ Department of Environmental Sciences, University of California, Riverside, CA 92521, USA. ${ }^{4}$ Laboratorio de Genética y Acuicultura, Universidad de Los Lagos, Avenida Fuchslocher 1305, Osorno, Chile.

*Corresponding author: crowley@ucr.edu

\begin{abstract}
Rhizobacteria are capable of stimulating plant growth through a variety of mechanisms that include improvement of plant nutrition, production and regulation of phytohormones, and suppression of disease causing organisms. While considerable research has demonstrated their potential utility, the successful application of plant growth promoting rhizobacteria (PGPR) in the field has been limited by a lack of knowledge of ecological factors that determine their survival and activity in the plant rhizosphere. To be effective, PGPR must maintain a critical population density of active cells. Inoculation with PGPR strains can temporarily enhance the population size, but inoculants often have poor survival and compete with indigenous bacteria for available growth substrates. PGPR often have more than one mechanism for enhancing plant growth and experimental evidence suggests that the plant growth stimulation is the net result of multiple mechanisms of action that may be activated simultaneously. The aim of this review is to describe PGPR modes of action and discuss practical considerations for PGPR use in agriculture.
\end{abstract}

Keywords: Agricultural inoculant, phytohormone, phytopathogen biocontrol, plant nutrition, rhizosphere.

\section{INTRODUCTION}

Plant growth promoting rhizobacteria (PGPR) influence plant health and productivity by a variety of mechanisms that involve solubilization of mineral nutrients, stimulation of root growth, and suppression of root diseases. Since the first studies on PGPR in the 1950's, many hundreds of candidate PGPR strains have been screened and evaluated in laboratory, greenhouse and field studies across the world. Today PGPR are commonly used in developing countries, and inoculants are used on millions of hectares of land (Zehnder et al., 2001). Nevertheless, implementation of this biotechnology has been hindered by the lack of consistency and variation in responses that are obtained in field trials from site to site, year to year, or for different crops (Lambert and Joos, 1989). 
Successful establishment of the introduced bacteria depends on proper PGPR selection that must be tailored to the soil and crop combination. Other basic problems that are related to inoculum production, storage, and delivery have mostly precluded the use of non-spore forming bacteria as soil inoculants. Lastly, there has been considerable confusion over the precise effects of PGPR, which confounds scientific studies aimed at quantifying their contribution to plant growth. This is largely due to poor understanding of the interactions between PGPR and their plant hosts and the resident microflora, as well as a paucity of information on how environmental factors influence processes that contribute to plant growth promotion.

Two paradigms that have emerged so far from the study of PGPR is that many of the best strains are multifunctional, and secondly, that PGPR traits are commonly distributed among many different species and genera of microorganisms, many of which are indigenous members of the soil microbial community. In most cases, individual strains vary considerably in performance and there is no clear relationship between taxonomy and PGPR functions that can be used to monitor the population size and activity of these bacteria based on quantification of specific taxonomic groups in the soil. The possibility that indigenous PGPR affect the relative performance of introduced PGPR inoculants is quite high, so without knowledge of background PGPR activity, the response to soil inoculation is difficult to predict. Many PGPR simultaneously solubilize phosphorus, produce auxins that stimulate root growth, and produce antibiotics and siderophores that may function in suppression of root disease. Other traits that may contribute to plant growth promotion include production of substances that induce systemic resistance or enzymes degrading hydrogen cyanide or ethylene and reactive oxygen species that are produced by plants during environmental stress. Lastly, the phenomenon of quorum regulation can affect the expression of each of these traits as PGPR interact with the resident microbial community (reviewed by Lugtenberg and Kamilova, 2009). In this manner, critical threshold population sizes are likely required to induce the expression of some traits, particularly those involved in biocontrol. Altogether any and all of the cumulative effects of PGPR that influence root growth rates, root system architecture, root hair formation and longevity, will indirectly affect the ability to acquire water and nutrients and to tolerate root loss to disease. Deciphering which mechanisms are most important and how to manage the soil microflora to obtain expression of these traits is so the remaining great challenge for consistent PGPR use in agricultural systems.

In this review, we examine the types of PGPR bacteria that have been identified to date and their functional characteristics. We also examine briefly inoculum production and delivery technologies and the advantages and disadvantages of various methods for introducing and maintaining high population densities of PGPR that are needed in order to be effective.

\section{GENERAL CHARACTERISTICS OF PGPR}

PGPR have been subjected to numerous investigations focused on biotechnological applications in agriculture, horticulture, forestry and environmental protection (Zahir et al., 2004). Early studies in the 1950's began with a focus on nitrogen fixing bacteria. Since then, a large number of PGPR belonging to different bacterial classes and genera with 
multifunctional traits have been described (Rodríguez-Díaz et al., 2008). PGPR strains are broadly distributed among many taxa including Actinobacteria, Bacteroidetes, Cyanobacteria, Firmicutes and Proteobacteria (Tilak et al., 2005), such that determination of the background population size and activity of PGPR in resident microbial communities is difficult to assess based on analysis of microbial community structure or abundance of a particular taxonomic group. The main aim of biotechnological development based on PGPR has been to develop soil inoculants that can contribute to sustainable agriculture, thereby diminishing the need for use of chemical fertilizers and pesticides (Adesemoye and Kloepper, 2009).

Based on our present knowledge, the interactions between bacteria and plants can be classified into three categories: neutral, negative or positive (Whipps, 2001). Most rhizobacteria associated with plants are commensals, in which bacteria establish an innocuous interaction that does not have any visible effect on the growth and physiology of the plant (Beattie, 2006). The rhizosphere also contains rhizobacteria that negatively influence the growth and physiology of the plants, and includes phytopathogens (Beattie, 2006). In addition to parasitic and disease causing organisms, such bacteria include those that produce phytotoxic substances, such as hydrogen cyanide or ethylene that inhibit root growth. Counter to these deleterious bacteria are PGPR, which exert a positive effect on plant growth by direct mechanisms such as solubilization of nutrients, nitrogen fixation, production of growth regulators, etc., or by indirect mechanisms such as stimulation of mycorrhizae development, competitive exclusion of pathogens, or removal of phytotoxic substances that are produced by deleterious bacteria and plant roots under stress condition mechanisms (Beattie, 2006; Bashan and de-Bashan, 2010).

In addition to these functional classifications, PGPR can be further grouped with respect to the plant compartment that they occupy as either intracellular (iPGPR, symbiotics) or extracellular (ePGPR, free living), in accordance with the degree of association with the root cells. The iPGPR may live inside the root cells, generally in specialized structures, such as nodules. Extracellular ePGPR are situated either in the rhizosphere, on the root surface (rhizoplane) or in the intercellular spaces of the root cortex, colonizing the plant tissue intercellularly (Gray and Smith, 2005).

In accordance with the mechanisms presented by PGPR, classification terms have been established (Table 1) to describe their activities and mechanisms by which these functions are achieved. In general, direct mechanisms are those affecting the balance of plant's growth regulators, enhancing plant's nutritional status and stimulating systemic disease resistance mechanisms (Zahir et al., 2004; Glick et al., 2007). Indirect mechanisms are related to biocontrol, including antibiotic production, chelation of available $\mathrm{Fe}$ in the rhizosphere, synthesis of extracellular enzymes that hydrolyze the fungal cellular wall and competition for niches within the rhizosphere (Zahir et al., 2004; Glick et al., 2007). This classification has led to the application of generic terms including: biofertilizer, phytostimulator and biopesticide to describe the primary function. Nonetheless, many bacteria have dual roles, which can lead to confusion. The best example of such confusion is found in the body of work on Azospirillum, which initially was based on this bacterium's ability to fix nitrogen, but which was later shown to affect plant 
growth by production of phytohormones. Since then, it has been classified primarily as a phytostimulator (Okon and Kapulnik, 1986; Spaepen et al., 2008). Similarly, many phosphorus-solubilizing bacteria have been screened and selected based on their ability to solubilize hydroxyapatite on agar media, but they have later been found to affect root growth by production of plant growth hormones. Despite the confusion generated by multifunctional PGPR, it is worthwhile to examine the traits associated with each of the three generic descriptors that are used to classify PGPR.

\section{CONTRIBUTION OF RHIZO- BACTERIA TO PLANT NUTRITION}

Microorganisms having mechanisms that facilitate nutrient uptake or increase nutrient availability or stimulate plant growth are commonly referred to as biofertilizers. Biofertilizers are considered as an alternative or complement to chemical fertilization to increase the production of crops in low input agricultural systems. There are some PGPR that can fix nitrogen, solubilize mineral nutrients and mineralize organic compounds. The most well-studied PGPR considered biofertilizers correspond to nitrogen fixation and utilization of insoluble forms of phosphorus.

\section{Agronomic significance of biological nitrogen fixation}

Nitrogen (N) is one of the principal plant nutrients, and its low availability due to the high losses by emission or leaching is a limiting factor in agricultural ecosystems, hence bacteria with ability to make atmospheric $\mathrm{N}$ available for plants play a critical role. There are two types of biological fixation: symbiotic and nonsymbiotic. The first is the most important mechanism by which most atmospheric $\mathrm{N}$ is fixed, but it is limited to legume plant species and various trees and shrubs that form actinorrhizal roots with Frankia. This process is carried out in well defined nodule structures. Among the most studied symbiotic bacteria are Rhizobium, Bradyrhizobium, Sinorhizobium and Mesorhizobium (Zahran, 2001). Although the beneficial effects of the symbiotic association of rhizobia with legume plants is known, these bacteria are not considered PGPR, except when associated with non-legume plants (Dobbelaere et al., 2003). On the other hand, nonsymbiotic biological $\mathrm{N}$ fixation, is carried out by free living diazotrophics, and this can stimulate non-legume plants growth (Antoun et al., 1998). There are studies showing that N-fixing bacteria, free-living as well as Rhizobium strains, can stimulate the growth of non-legumes such as radish (Antoun et al., 1998) and rice (Mirza et al., 2006), in this way contributing to reduced dependence on $\mathrm{N}$ based fertilizers (Bhattacharjee et al., 2008). Non-symbiotic N-fixing rhizospheric bacteria belonging to genera including Azoarcus (Reinhold-Hurek et al., 1993), Azospirillum (Bashan and deBashan, 2010), Burkholderia (Estrada de los Santos et al., 2001), Gluconacetobacter (Fuentes-Ramírez et al., 2001) and Pseudomonas (Mirza et al., 2006) have been isolated from different soils.

Due to the high energy requirement for $\mathrm{N}$ fixation and relatively low metabolic activity of free living organisms that must compete for root exudates outside a nodule environment, the ability of nonsymbiotic bacteria to fix significant quantities of $\mathrm{N}$ is limited. The presence of a diazotrophic bacterium in the rhizosphere of a certain plant is no longer considered to imply that such bacteria make a substantial contribution to $\mathrm{N}$ fixation and $\mathrm{N}$ supply for plant growth. Although the $\mathrm{N}$ fixing capacity of certain 
J. Soil Sci. Plant Nutr. 10 (3): 293 - 319 (2010)

Table 1. Terms adopted for classified mechanisms by which plant growth promoting bacteria stimulate plant growth.




bacteria can easily be demonstrated under in vitro conditions, its demonstration in greenhouse and field studies is more complex and highly variable. Some observations suggest that rhizobacteria can provide crops with significant quantities of N (Dobbelaere et al., 2003). Nevertheless, studies in sorghum, maize and wheat inoculated with Azospirillum have revealed a contribution of only $5 \mathrm{~kg}$ $\mathrm{N}$ ha $^{-1} \mathrm{yr}^{-1}$ (Okon and LanbanderaGonzalez, 1994). This quantity pales in importance when compared with the application of $\mathrm{N}$ fertilizers in a range of $150-200 \mathrm{~kg} N \mathrm{ha}^{-1} \mathrm{yr}^{-1}$, which is commonly practiced in modern agriculture. This applies likely to other free living $\mathrm{N}$ fixers. Recently, Unkovich and Baldock (2008) pointed out that the contribution of $\mathrm{N}$ by free living soil bacteria for crop growth in Australia is probably $<10 \mathrm{~kg} \mathrm{ha}^{-1} \mathrm{yr}^{-1}$. Peoples et al. (2002) present a $\mathrm{N}$ fixation value of 0 to $15 \mathrm{~kg} \mathrm{ha}^{-1} \mathrm{yr}^{-1}$ and Bottomley and Myrold (2007) suggest annual values between <1 and $10 \mathrm{~kg} \mathrm{ha}^{-1}$. For this reason, the ability of PGPR to fix $\mathrm{N}$ is no longer an important criterion for classification of a bacterium as a biofertilizer.

Enhancing phosphorus availability for plant growth by rhizobacteria

Phosphorus (P) is an essential plant nutrient with low availability in many agricultural soils. Today many agricultural soils have a high total $\mathrm{P}$ content due to the application of $\mathrm{P}$ fertilizers over long periods of time. On the other hand, much of this $\mathrm{P}$ is in mineral forms and is only slowly available to plants (reviewed by Rodríguez et al., 2006 and Richardson et al., 2009). Most of the insoluble $\mathrm{P}$ forms are present as aluminum and iron phosphates in acid soils (Mullen, 2005), and calcium phosphates in alkaline soils (Goldstein and Krishnaraj, 2007). The ability of rhizosphere bacteria to solubilize insoluble $\mathrm{P}$ minerals has been attributed to their capacity to reduce $\mathrm{pH}$ by the excretion of organic acids (e.g. gluconate, citrate, lactate and succionate) and protons (during the assimilation of $\mathrm{NH}^{+}$) (Gyaneshwar et al., 1999; Mullen, 2005). These bacteria have been characterized as members of the Bacillus, Burkholderia, Enterobacter, Klebsiella, Kluyvera, Streptomyces, Pantoea and Pseudomonas genera, (Chung et al., 2005: Hariprasad and Niranjana, 2009; Oliveira et al., 2009) in various studies of $\mathrm{P}$ solubilizing bacteria from different rhizospheric soils. These microorganisms grow in media with tricalcium phosphate or similar insoluble materials as the only phosphate source and not only assimilate the element, but also solubilize quantities in excess of their nutritional demands, thereby making it available for plants (Chen et al., 2006).

On the other hand, organic $\mathrm{P}$ can constitute between 30 and $50 \%$ of the total $\mathrm{P}$ of the soil, a high proportion of it corresponding to phytate (Borie et al., 1989; Turner et al., 2003). In this context, there are bacteria capable of producing phytase enzymes for the mineralization of phytates (Lim et al., 2007; Jorquera et al., 2008b). To date, there are only few studies reporting rhizobacteria capable of mineralizing the phytate. Among the phytase producing rhizobacteria, species belonging to Bacillus, Burkholderia, Enterobacter, Pseudomonas, Serratia and Staphylococcus genera are the most common culturable bacteria (Richardson and Hadobas, 1997: Hussin et al., 2007; Shedova et al., 2008). Many of these bacteria are remarkably efficient. Richardson and Hadobas (1997) isolated Pseudomonas spp. that utilized phytate from different soils in Australia. The isolated strains exhibited a high phytase activity, releasing over $80 \%$ of the $\mathrm{P}$ content in the phytate. In a later study 
utilizing plants with a limited capacity to obtain the P from phytate, Richardson et al. (2001) observed that the ability of pasture plants to acquire $\mathrm{P}$ from phytate was enhanced followed by inoculation with the specified Pseudomonas sp. strains. Similarly, Unno et al. (2005), isolated diverse bacteria with the ability to utilize phytate from the rhizosphere from white lupin (Lupinus albus). Almost all the isolates were classified as members of the Burkholderia genus and some of them significantly promoted the growth of the lupin. Jorquera et al. (2008a) isolated P solubilizing bacteria from the rhizospheres of five cultivated plants (Lolium perenne, Trifolium repens, Triticum aestivum, Avena sativa, Lupinus luteus), which presented more than one mechanism for utilizing insoluble forms of phosphorus. Moreover, all strains showed the capacity to produce $\mathrm{P}$ hydrolases. The major limitation today for use of these organisms is the lack of consistent effects in mobilizing $\mathrm{P}$ under field conditions. This is likely due to competition with the native microflora and environmental factors that either limit the population size or activity of the PGPR. It is now clear from many studies that evaluation and ranking of $\mathrm{P}$ solubilizing bacteria under laboratory conditions do not necessarily correspond to the efficacy of the PGPR for enhancing plant P uptake under field conditions (Richardson, 2001; Rengel, 2008). As with nitrogen fixing bacteria, the production of plant growth hormones that improve root surface area can have indirect effects on the ability to efficiently extract P from soil. Thus, it is likely that many so-called biofertilizers have dual action effects that are mediated by direct solubilization of inorganic $\mathrm{P}$, mineralization of organic $\mathrm{P}$, and stimulatory effects on plant root growth or mycorrhizae formation.

\section{PRODUCTION OF PHYTO- HORMONES AND REGULATION OF ETHYLENE LEVELS IN PLANT}

The production of phytohormones by PGPR is now considered to be one of the most important mechanisms by which many rhizobacteria promote plant growth (Spaepen et al., 2007). Phytohormones are signal molecules acting as chemical messengers and play a fundamental role as growth and development regulators in the plants. Phytohormones are organic compounds that in extremely low concentrations influence biochemical, physiological and morphological processes in plants, and their synthesis is finely regulated (Fuentes-Ramírez and Caballero-Mellado, 2006). Numerous fungal and bacterial species can produce phytohormones (Tsavkelova et al., 2006). The phytohormone producing ability is widely distributed among bacteria associated with soil and plants. Studies have demonstrated that the PGPR can stimulate plant growth through the production of auxins (indole acetic acid) (Spaepen et al., 2008), gibberellines (Bottini et al., 2004) and cytokinins (Timmusk et al., 1999), or by regulating the high levels of endogenous ethylene in the plant (Glick et al., 1998).

\section{Indole acetic acid (IAA) producing rhizobacteria}

Many important plant-microbial interactions center on the production of auxins, IAA being the main plant auxin. The IAA is responsible for the division, expansion and differentiation of plant cells and tissues and stimulates root elongation. The ability to synthesize IAA has been detected in many rhizobacteria as well as in pathogenic, symbiotic and free living bacterial species (Costacurta et al., 1995; Tsavkelova et al., 2006). 
At present, auxin synthesizing rhizobacteria are the most well-studied phytohormone producers (Tsavkelova et al., 2006; Spaepen et al., 2007). These rhizobacteria synthesize IAA from tryptophan by different pathways, although it can also be synthesized via tryptophan-independent pathways, though in lower quantities (Spaepen et al., 2007). Phytopathogenic bacteria mainly use the indole acetamide pathway to synthesize IAA, which has been implicated in tumor induction in plants. It is not clear whether it is used by beneficial bacteria. In contrast, the acid indole pyruvic pathway appears to be the main pathway present in plant growth promoting beneficial bacteria (Patten and Glick, 2002).

Among PGPR species, Azospirillum is one of the best studied IAA producers (Dobbelaere et al., 1999). Other IAA producing bacteria belonging to Aeromonas (Halda-Alija, 2003), Azotobacter (Ahmad et al., 2008), Bacillus (Swain et al., 2007), Burkholderia (Halda-Alija, 2003), Enterobacter (Shoebitz et al., 2009), Pseudomonas (Hariprasad and Niranjana, 2009) and Rhizobium (Ghosh et al., 2008) genera have been isolated from different rhizosphere soils. Inoculation with IAA producing PGPR has been used to stimulate seed germination, to accelerate root growth and modify the architecture of the root system, and to increase the root biomass. In recent studies, Tsavkelova et al. (2007) have extended beyond individual strains as inoculants and reported an increase in the germination of orchid seeds (Dendrobium moschatum) inoculated with Sphingomonas sp. and IAA producing Mycobacterium sp. In addition to stimulating root growth, IAA producing bacteria can also be used to stimulate tuber growth. Swain et al. (2007) reported a positive effect of Bacillus subtilis IAA producing strains on the edible tubercle Dioscorea rotundata $\mathrm{L}$ in one of their studies. They applied a suspension of $B$. subtilis on the surface of the plants, which resulted in an increase in stem and root length, increased fresh weight of the stem and root, an increase in the root:stem ratio and increased numbers of sprouts as compared with non-inoculated plants.

\section{Regulating plant ethylene levels by rhizobacteria}

Ethylene is essential for the growth and development of plants, but it has different effects on plant growth depending on its concentration in root tissues. At high concentrations, it can be harmful, as it induces defoliation and cellular processes that lead to inhibition of stem and root growth as well as premature senescence, all of which lead to reduced crop performance ( $\mathrm{Li}$ et al., 2005). Under different types of environmental stress, such as cold, draught, flooding, infections with pathogens, presence of heavy metals, among others, plants respond by synthesizing 1-aminocyclopropane-1carboxylate (ACC), which is the precursor for ethylene (Chen et al., 2002; Glick, 2007). Some of the ACC is secreted into the rhizosphere and is readsorbed by the roots, where it is converted into ethylene. This accumulation of ethylene leads to a downward spiral effect, as poor root growth leads to a diminished ability to acquire water and nutrients, which, in turn, leads to further stress. Thus, PGPR with the ability to degrade ACC in the rhizosphere can help to break this downward cycle and reestablish a healthy root system that is needed to cope with environmental stress.

The primary mechanism, that is used by rhizobacteria that degrade ethylene, is 
the destruction of ethylene via the enzyme ACC deaminase (EC 4.1.99.4). This enzyme can diminish or prevent some of the harmful effects of the high ethylene levels (Glick et al., 1998). The ACC deaminase acts on ACC, an immediate ethylene precursor in higher plants, degrading this chemical to alphaketobutyrate and ammonium, (Glick et al., 1998; Grichko and Glick, 2001; Mayak et al., 2004). Rhizosphere bacteria with ACC deaminase activity belonging to the Achromobacter (Govindasamy et al., 2008), Azospirillum (Li et al., 2005), Bacillus (Ghosh et al., 2003), Enterobacter (Li et al., 2001), Pseudomonas (Govindasamy et al., 2008) and Rhizobium (Duan et al., 2009) genera have been isolated from different soils.

Various studies have demonstrated that plants treated with PGPR bacteria that produce ACC deaminase have increased their resistance to environmental stress. Grinchko and Glick (2001) inoculated tomato seeds with the ACC deaminase expressing bacteria Enterobacter cloacae and Pseudomonas putida and registered an increase in plant resistance on 55 days of age to 9 consecutive days of flooding. Ghosh et al. (2003) found ACC deaminase activity in three Bacillus species (Bacillus circulans DUC1, Bacillus firmus DUC2 and Bacillus globisporus DUC3), which stimulated root elongation of Brassica campestri plants. Mayak et al. (2004) evaluated tomato plants inoculated with the bacterium Achromobacter piechaudii under water and saline stress conditions. The authors reported a significant increase in fresh and dry weight of inoculated plants. In soils with a high copper content, Reed and Glick (2005) reported an increase in dry matter content of the root and the air part in raps seeds inoculated with the ACC deaminase producing bacterium Pseudomonas asplenii.

\section{BIOCONTROL OF MICRO- ORGANISMS CAUSING PLANT DISEASE}

Phytopathogenic microorganisms have a great impact on crop yields and can significantly reduce plant performance and crop quality. The usual strategy for the control of phytopathogens is to apply chemical pesticides, but this strategy has led to increased concerns over environmental contamination and has resulted in the so-called pesticide treadmill in which pathogens develop resistance to individual chemical controls over time, needing a constant development of new pesticides (Fernando et al., 2006). In this context, rhizobacteria that can provide biocontrol of disease or insect pests (biopesticides) are considered an alternative to chemical pesticides (Zahir et al., 2004). A large number of mechanisms are involved in biocontrol and can involve direct antagonism via production of antibiotics, siderophores, HCN, hydrolytic enzymes (chitinases, proteases, lipases, etc.), or indirect mechanisms in which the biocontrol organisms act as a probiotic by competing with the pathogen for a niche (infection and nutrient sites). Biocontrol can also be mediated by activation of the acquired systemic resistance (SAR), induced systemic resistance (ISR) responses in plants, and by modification of hormonal levels (Bowen and Rovira, 1999; van Loon, 2007) in the plant tissues.

\section{Antibiotic-producing rhizobacteria}

The production of antibiotics is considered one of the most powerful and studied biocontrol mechanisms for combating phytopathogens. Antibiotics onstitute a wide and heterogeneous group of low molecular weight chemical organic compounds that are produced by a wide variety of microorganisms (Raaijmakers 
et al., 2002). Under laboratory conditions many different types of antibiotics produced by PGPR have shown to be effective against phytopathogenic agents (Bowen and Rovira, 1999). The antibiotics produced by PGPR include: butyrolactones, zwittermycin A, kanosamine, oligomycin A, oomycin A, phenazine-1-carboxylic acid, pyoluteorin, pyrrolnitrin, viscosinamide, xanthobaccin, and 2,4-diacetyl phloroglucinol (2,4DAPG) (Whipps, 2001). The last is one of the most efficient antibiotics in the control of plant pathogens (Fernando et al., 2006) and can be produced by various strains of Pseudomonas, one of the most common bacterial species of the rhizosphere (Rezzonico et al., 2007). The 2,4-DAPG has a wide spectrum of properties in that it is antifungal (Loper and Gross, 2007; Rezzonico et al., 2007), antibacterial (Velusamy et al., 2006) and antihelmintic (Cronin et al., 1997). In soils, it suppresses the growth of the wheat pathogenic fungus Gaeumannomyces graminis var. tritici, Raaijmakers et al. (1999) reported a production of $0.62 \mathrm{ng}$ 2,4-DAPG per $10^{5}-10^{7} \mathrm{CFU} \mathrm{g}^{-1}$ root by $P$. fluorescens, strain Q2-87.

\section{Hydrogen cyanide (HCN) producing rhizobacteria}

Apart from the production of 2,4-DAPG, some rhizobacteria are capable of producing HCN (hydrogen cyanide, also known as cyanide) (Rezzonico et al., 2007). HCN is a volatile, secondary metabolite that suppresses the development of microorganisms and that also affects negatively the growth and development of plants (Siddiqui et al., 2006). HCN is a powerful inhibitor of many metal enzymes, especially copper containing cytochrome $\mathrm{C}$ oxidases. HCN is formed from glycine through the action of HCN synthetase enzyme, which is associated with the plasma membrane of certain rhizobacteria (reviewed by Blumer and Haas, 2000). To date many different bacterial genera have shown to be capable of producing $\mathrm{HCN}$, including species of Alcaligenes, Aeromonas, Bacillus, Pseudomonas and Rhizobium (Devi et al., 2007; Ahmad et al., 2008). HCN production is a common trait within the group of Pseudomonas present in the rhizosphere, with some studies showing that about $50 \%$ of pseudomonads isolated from potato and wheat rhizosphere are able to produce HCN in vitro (Bakker and Schippers, 1987; Schippers et al., 1990).

Various studies attribute a diseaseprotective effect to $\mathrm{HCN}$, e.g. in the suppression of "root-knot" and black rot in tomato and tobacco root caused by the nematodes Meloidogyne javanica and Thielaviopsis basicota, respectively (Voisard et al., 1989; Siddiqui et al., 2006). The subterranean termite Odontotermes obesus, an important pest in agricultural and forestry crops in India, is also controlled by HCN (Devi et al., 2007). However, there are investigations reporting harmful effects on plants, inhibition of energy metabolism of potato root cells (Bakker and Schippers, 1987), and reduced root growth in lettuce (Alström and Burns, 1989). Likewise, HCN produced by Pseudomonas in the rhizosphere inhibits the primary growth of roots in Arabidopsis due to the suppression of an auxin responsive gene (Rudrappa et al., 2008).

\section{Siderophore-producing rhizobacteria}

Siderophores are low molecular weight compounds that are produced and utilized by bacteria and fungi as iron (Fe) chelating agents. These compounds are produced by various types of bacteria in response to iron deficiency which normally occurs in neutral to alkaline $\mathrm{pH}$ soils, due to low iron solubility at elevated pH (Sharma and Johri, 2003). Iron is 
essential for cellular growth and metabolism, such that $\mathrm{Fe}$ acquisition through siderophore production plays an essential role in determining the competitive fitness of bacteria to colonize plant roots and to compete for iron with other microorganisms in the rhizosphere (see reviews: Crowley and Gries, 1994; Crowley, 2006). Siderophore producing PGPR can prevent the proliferation of pathogenic microorganisms by sequestering $\mathrm{Fe}^{3+}$ in the area around the root (Siddiqui, 2006). Fe depletion in the rhizosphere does not affect the plant, as the low $\mathrm{Fe}$ concentrations occur at microsites of high microbial activity during establishment of the pathogen. Many plants can use various bacterial siderophores as iron sources, although the total concentrations are probably too low to contribute substantially to plant iron uptake. Plants also utilize their own mechanisms to acquire iron; dicots via a root membrane reductase protein that converts insoluble $\mathrm{Fe}^{3+}$ into the more soluble $\mathrm{Fe}^{2+}$ ion, or in the case of monocots by production of phytosiderophores (Crowley, 2006). Various studies have isolated siderophoreproducing bacteria belonging to the Bradyrhizobium (Khandelwal et al., 2002), Pseudomonas (Boopathi and Rao, 1999), Rhizobium (Roy and Chakrabartty, 2000), Serratia (Kuffner et al., 2008) and Streptomyces (Kuffner et al., 2008) genera from the rhizosphere.

Carrillo-Castañeda et al. (2002) reported positive effects on alfalfa plantlet growth after the inoculation of siderophore producing Pseudomonas, Rhizobium and Azospirillum grown in iron limited cultures. The inoculated alfalfa seeds increased their germination as well as the root and stem dry weight. Nevertheless, as with other PGPR, the growth promotion that occurred may be due to other mechanisms or combinations of mechanisms that increase nutrient availability, suppress pathogens, or affect root growth via hormone production.

\section{PGPR WITH MULTIPLE MECHANISMS OF ACTION}

The notion of multiple mechanisms emerged from early studies on Azospirillum, when the results of the field inoculation experiments failed to demonstrate that $\mathrm{N}$-fixation was the main mechanism by which plant growth was stimulated (Bashan et al., 1989; Bashan and Levanony, 1990). Failing N fixation as an explanation, the additive hypothesis was then proposed to describe the effect of Azospirillum on plant growth (Bashan and Levanony, 1990). The additive hypothesis proposes the possibility of multiple mechanisms that function simultaneously or sequentially (Bashan and de-Bashan, 2010). In the case of Azospirillum, $\mathrm{N}$ fixation has largely been discounted and primary plant growth promotion mechanism is now attributed to several other functions including phytohormones production (Dobbelaere et al., 1999; Malhotra and Srivastava, 2008), ACC deaminase activity (Li et al., 2005) and hydrolytic enzyme production (Mostajeran et al., 2007). Today, it is increasingly recognized that many PGPR strain likely function by more than one mechanism (de Freitas et al., 1997). Examples of such bacteria are described in (Table 2) that refers to multiple mechanisms of action for various PGPR isolates (Vassilev et al., 2006; Ahmad et al., 2008; Avis et al., 2008).

Two recent reviews reconsider the importance of the presence of multiple action mechanisms promoting plant growth in the microorganisms. Vassilev et al. (2006) reviewed the potential of phosphorus solubilizing microorganisms that can provide simultaneously phytopathogen biocontrol, and also affect 
plant growth via production of siderophores, hydrolytical enzymes and IAA. A second review by Avis et al. (2008) classified PGPR bacteria into two groups based on the main action mechanisms by which they are known. These two groups are: (i) microorganisms with direct plant growth promoting mechanisms (e.g. phytohormone production, phosphorus solubilization, etc.), and (ii) microorganisms which indirectly promote plant growth and productivity through biocontrol of phytopathogens (e.g. production of siderophores, antibiotics, HCN, etc.). Despite this arbitrary classification, microorganisms of both groups can simultaneously contain secondary mechanisms.

\section{PRACTICAL CONSIDERATIONS IN THE USE OF PGPR}

Studies on the use of PGPR inoculants have been conducted under laboratory (soil microcosms), greenhouse and field conditions (Table 3), but they can often lead to inconsistent results when compared under different experimental conditions. Many experiments have demonstrated the growth stimulation of plant crops in the greenhouse, resulting in increased yield parameters and in the control on soil-borne pathogenic organisms. However, the replication of successful results of PGPR applications under field conditions has been limited by the lack of knowledge about their ecology, survival and activity in the plant rhizosphere. The main aspects related to the application of bacterial inoculants are discussed below.

\section{Efficacy of PGPR inoculation}

PGPR efficacy is dependent on establishing an effective population density of active cells in plant rhizosphere. As this is a simple principle, it has proved to be difficult to establish dose response effects in which the degree of plant growth promotion or disease suppression can be directly correlated with size of the PGPR population. In general, bacterial suspensions of PGPR are prepared at densities of $10^{8}$ to $10^{9}$ CFU $\mathrm{ml}^{-1}$ for root dipping and soil inoculation. After inoculation at these high densities, the cell numbers will undergo a rapid decline depending on whether or not the soil has been sterilized. In autoclaved soils, inoculants will typically persist at cell densities of $10^{7}$ to $10^{8} \mathrm{CFU} \mathrm{g}^{-1}$ soil for many weeks. In nonsterile soils where there is competition with the resident flora and predation by protozoa and nematodes, bacterial populations will decline rapidly by orders of magnitude per week until the population reaches equilibrium with its environment. This likely accounts for differences that are observed in lab and greenhouse studies where soils are sterilized, versus in the field where results of PGPR inoculation are much more inconsistent.

Inoculation efficacy depends on the rhizosphere competence of the bacteria for the particular host plant. In studies examining the induction of systemic induced resistance to foliar and systemic pathogens, model systems with cucumber, carnation, and bean show that effective root colonization levels can be achieved by seed coating with high numbers of bacteria or by use of bacteria suspensions to dip the plant roots or inoculate the soil at the time of transplanting (Zehnder et al., 2001). To maintain effective cell densities under field conditions, it is often necessary to reinoculate at intervals during the production period. The latter strategy is limited by the high cost of inoculum production, difficulty in maintaining viable cells for long periods 
Table 2. Promoting growth plant rhizobacteria strains with multiple mechanisms.

\begin{tabular}{|c|c|c|c|c|c|c|c|}
\hline Species & $\mathbf{C P}$ & IAA & ACCD & HCN & SID & $\begin{array}{c}\text { Other } \\
\text { mechanisms }\end{array}$ & Reference \\
\hline Azotobacter chroococcum A4 & + & + & ND & + & + & & Wani et al., 2007 \\
\hline Bacillus sp. PSB1 & + & + & ND & + & + & & Wani et al., 2007 \\
\hline Bacillus sp. PSB10 & + & + & ND & + & + & & Wani et al., 2007 \\
\hline Enterobacter BNM 0357 & + & + & ND & ND & ND & Nitrogenase + & Shoebitz et al., 2009 \\
\hline Enterobacter sp. NBRI K28 & + & + & + & ND & + & & Kumar et al., 2008 \\
\hline Pseudomonas sp. SF4c & - & + & - & ND & + & & Fischer et al., 2007 \\
\hline Pseudomonas aeruginosa BFPB9 & + & + & ND & + & + & $\begin{array}{l}\text { Protease+, } \\
\text { Cellulase+ }\end{array}$ & Jha et al., 2009 \\
\hline P. fluorescens PSRB21 & + & + & ND & ND & + & & Hariprasad and Niranjana, 2009 \\
\hline P. mosselli FP13 & + & + & ND & - & + & Protease+ & Jha et al., 2009 \\
\hline P. fluorescens biotype G (N3) & ND & + & + & ND & ND & Chitinase+ + & Shaharoona et al., 2006 \\
\hline P. plecoglossicida FP12 & + & + & ND & - & + & Protease+ + & Jha et al., 2009 \\
\hline P. putida PSRB6 & + & + & ND & ND & + & Chitinase+ & Hariprasad and Niranjana, 2009 \\
\hline Serratia marcescens & ND & + & ND & ND & + & & Kuffner et al., 2008 \\
\hline
\end{tabular}

CP: tricalcic phosphate solubilization; IAA: Indol acetic acid production; ACCD: ACC deaminase activity; HCN: Hydrogen cyanide production; SID: Siderophore production; + positive, - negative, ND: not done. 
Table 3. Plant crop response to PGPR inoculation under different experimental conditions.

\begin{tabular}{|c|c|c|c|c|c|c|}
\hline Plant & $\begin{array}{l}\text { PGPR } \\
\text { inoculant }\end{array}$ & $\begin{array}{l}\text { PGPR } \\
\text { mechanisms } \\
\text { involved }\end{array}$ & $\begin{array}{l}\text { Plant growth parameter } \\
\text { (measure unit) }\end{array}$ & $\begin{array}{c}\text { Increased } \\
\text { plant } \\
\text { parameters }^{\mathrm{a}} \\
(\%) \\
\end{array}$ & $\begin{array}{l}\text { Assay condition } \\
\text { and limitation }\end{array}$ & Reference \\
\hline $\begin{array}{l}\text { Cotton } \\
\text { (Gossypium } \\
\text { sp.) }\end{array}$ & $\begin{array}{l}\text { Bacillus subtilis } \\
\text { FZB 24® }\end{array}$ & $\begin{array}{l}\text { IAA } \\
\text { production, } \\
\text { phytase } \\
\text { activity and } \\
\text { antibiotics } \\
\text { production }\end{array}$ & $\begin{array}{l}\text { - Average yield }\left(\mathrm{t} \mathrm{ha}^{-1}\right) \\
\text { - Bolls/plant mean number } \\
\text { - Mean plant height cm }\end{array}$ & $\begin{array}{l}31 \\
19 \\
11\end{array}$ & $\begin{array}{l}\text { - Field experiment } \\
\text { - Commercial strain }\end{array}$ & $\begin{array}{l}\text { Yao et al., } \\
2006\end{array}$ \\
\hline
\end{tabular}

${ }^{a}$ Percentage increase over non-inoculated control 
Continued ...

\begin{tabular}{|c|c|c|c|c|c|c|}
\hline Plant & $\begin{array}{l}\text { PGPR } \\
\text { inoculant }\end{array}$ & $\begin{array}{l}\text { PGPR } \\
\text { mechanisms } \\
\text { involved }\end{array}$ & $\begin{array}{l}\text { Plant growth parameter } \\
\text { (measure unit) }\end{array}$ & $\begin{array}{c}\text { Increased } \\
\text { plant } \\
\text { parameters } \\
(\%)\end{array}$ & $\begin{array}{l}\text { Assay condition } \\
\text { and limitation }\end{array}$ & Reference \\
\hline $\begin{array}{l}\text { Maize } \\
\text { (Zea mays L.) }\end{array}$ & $\begin{array}{l}\text { Pseudomonas } \\
\text { fluorescens } \\
\text { (MPp4), } \\
\text { Burkholderia sp. } \\
\text { (MBp1, MBf21 } \\
\text { and } \\
\text { MBf15) }\end{array}$ & $\begin{array}{l}\text { IAA } \\
\text { production and } \\
\text { antagonism } \\
\text { against } \\
\text { Fusarium } \\
\text { verticillioides }\end{array}$ & $\begin{array}{l}\text { - Shoot length (cm) } \\
\text { - Longest root length (cm) } \\
\text { - Shoot fresh weight (g) } \\
\text { - Root fresh weight (g) } \\
\text { - Plants showing disease } \\
\text { symptoms (\%) } \\
\text { - Disease reduction (\%) }\end{array}$ & $\begin{array}{l}30-32 \\
47-63 \\
24-32 \\
76-88 \\
10-30 \\
60-87\end{array}$ & $\begin{array}{l}\text { - Microcosm and } \\
\text { greenhouse } \\
\text { experiments } \\
\text { - Non commercial } \\
\text { strains } \\
\text { - Not proven at field } \\
\text { level }\end{array}$ & $\begin{array}{l}\text { Hernández- } \\
\text { Rodríguez } \\
\text { et al., } 2008\end{array}$ \\
\hline $\begin{array}{l}\text { Oat } \\
\text { (Avena sativa } \\
\text { L) }\end{array}$ & $\begin{array}{l}\text { Azospirillum sp. } \\
\text { (ChO6 and } \\
\text { ChO8) } \\
\text { Azotobacter } \\
\text { sp.(ChO5) } \\
\text { Pseudomonas } \\
\text { sp. (ChO9) }\end{array}$ & $\begin{array}{l}\text { IAA } \\
\text { production and } \\
\text { acetylene } \\
\text { reducing } \\
\text { activity }\end{array}$ & $\begin{array}{l}\text { - Root length }(\mathrm{mm}) \\
\text { - Root area }\left(\mathrm{cm}^{2}\right) \\
\text { - Shoot dry weight }\left(\mathrm{mg} \mathrm{plant}^{-1}\right) \\
\left.\text { - Total N (mg plant }{ }^{-1}\right) \\
\text { - Proportion of plant } \mathrm{N} \text { fixed } \\
\text { from the atmosphere (\% Ndfa) }\end{array}$ & $\begin{array}{l}-12-23 \\
8-500 \\
6-93 \\
-50-50 \\
50-64\end{array}$ & $\begin{array}{l}\text { - In vitro } \\
\text { - Non commercial } \\
\text { strains } \\
\text { - Not proven at field } \\
\text { level. }\end{array}$ & $\begin{array}{l}\text { Yao et al., } \\
2008\end{array}$ \\
\hline $\begin{array}{l}\text { Raspberry cv } \\
\text { Heritage } \\
\text { (Rubus spp) }\end{array}$ & Bacillus M3 & $\begin{array}{l}\text { N-fixing and } \\
\text { phosphate } \\
\text { solubilizing }\end{array}$ & $\begin{array}{l}\text { - Cane length }(\mathrm{cm}) \\
\text { - Cane diameter }(\mathrm{mm}) \\
\text { - Number of picks } \\
\text { - Number of cluster } \\
\text { - Number of berries } \\
\text { - Leaf area }\left(\mathrm{cm}^{2}\right) \\
\text { - Total soluble solid (\%) } \\
\text { - Titratable acids (\%) }\end{array}$ & $\begin{array}{c}13 \\
6 \\
-3 \\
25 \\
25 \\
14 \\
-0.9 \\
2\end{array}$ & $\begin{array}{l}\text { - Field experiment } \\
\text { - Non commercial } \\
\text { strains }\end{array}$ & $\begin{array}{l}\text { Orhan et al., } \\
2006\end{array}$ \\
\hline
\end{tabular}

${ }^{a}$ Percentage increase over non-inoculated control 
Continued....

\begin{tabular}{|c|c|c|c|c|c|c|}
\hline Plant & $\begin{array}{l}\text { PGPR } \\
\text { inoculant }\end{array}$ & $\begin{array}{l}\text { PGPR } \\
\text { mechanisms } \\
\text { involved }\end{array}$ & $\begin{array}{l}\text { Plant growth parameter } \\
\text { (measure unit) }\end{array}$ & $\begin{array}{l}\text { Increased plant } \\
\text { parameters }^{\mathrm{a}}(\%)\end{array}$ & $\begin{array}{l}\text { Assay condition } \\
\text { and limitation }\end{array}$ & Reference \\
\hline $\begin{array}{l}\text { Red pepper cv } \\
\text { Barodda } \\
\text { (Capsicum } \\
\text { annuum L.) }\end{array}$ & $\begin{array}{l}\text { Azospirillum } \\
\text { brasilense } \\
\text { CW903, } \\
\text { Burkholderia } \\
\text { pyrrocinia } \\
\text { CBPB-HOD, } \\
\text { Methylobacteriu } \\
\text { m oryzae } \\
\text { CBMB20 }\end{array}$ & $\begin{array}{l}\text { AA } \\
\text { production, } \\
\text { P solubilizing } \\
\text { and N fixing }\end{array}$ & $\begin{array}{l}\text { - Shoot length }(\mathrm{cm}) \\
\text { - Root length }(\mathrm{cm})\end{array}$ & $\begin{array}{c}4-35 \\
0.4-17\end{array}$ & $\begin{array}{l}\text { - Greenhouse } \\
\text { experiment } \\
\text { - Non commercial } \\
\text { strains } \\
\text { - Not proven at field } \\
\text { level. }\end{array}$ & $\begin{array}{l}\text { Madhaiyan } \\
\text { et al., } 2010\end{array}$ \\
\hline $\begin{array}{l}\text { Rice cv. } \\
\text { Dongjin } \\
\text { (Oryza sativa } \\
\text { L.) }\end{array}$ & $\begin{array}{l}\text { Azospirillum } \\
\text { brasilense } \\
\text { CW903, } \\
\text { Burkholderia } \\
\text { pyrrocinia } \\
\text { CBPB-HOD, } \\
\text { Methylobacteriu } \\
\text { m oryzae } \\
\text { CBMB20 }\end{array}$ & $\begin{array}{l}\text { IAA } \\
\text { production, } \\
\text { P solubilizing } \\
\text { and N fixing }\end{array}$ & $\begin{array}{l}\text { - Shoot length }(\mathrm{cm}) \\
\text { - Root length }(\mathrm{cm})\end{array}$ & $\begin{array}{l}1.5-8.5 \\
20-31\end{array}$ & $\begin{array}{l}\text { - Greenhouse } \\
\text { experiment } \\
\text { - Non commercial } \\
\text { strains } \\
\text { - Not proven at field } \\
\text { level. }\end{array}$ & $\begin{array}{l}\text { Madhaiyan } \\
\text { et al., } 2010\end{array}$ \\
\hline $\begin{array}{l}\text { Sorghum } \\
\text { (Sorghum } \\
\text { bicolour (L.) } \\
\text { Moench) }\end{array}$ & $\begin{array}{l}\text { B. cereus } \\
\text { (KBE7-8) } \\
\text { B. cereus } \\
\text { (NAS4-3) and } \\
\text { Stenotrophomon } \\
\text { as maltophilia } \\
\text { (KBS9-B) }\end{array}$ & $\begin{array}{l}\text { Siderophore } \\
\text { production, } \\
\text { IAA } \\
\text { production and } \\
\text { phosphate } \\
\text { solubilization }\end{array}$ & $\begin{array}{l}\text { - Shoot height (mm) } \\
\text { - Shoot fresh weight (g) } \\
\text { - Shoot dry weight (g) } \\
\text { - Chlorophyll (spad units) } \\
\text { - Leaf width (mm) } \\
\text { - Root length (mm) } \\
\text { - Root dry weight (g) }\end{array}$ & $\begin{array}{c}104-182 \\
1133-2255 \\
180-260 \\
68-78 \\
103-326 \\
214-279 \\
1300-1525\end{array}$ & $\begin{array}{l}\text { - Greenhouse pot } \\
\text { trial } \\
\text { - Non commercial } \\
\text { strains } \\
\text { - Not proven at field } \\
\text { level. }\end{array}$ & $\begin{array}{l}\text { Idris et al., } \\
2009\end{array}$ \\
\hline
\end{tabular}

${ }^{\text {a }}$ Percentage increase over non-inoculated control 
Continued.....

\begin{tabular}{|c|c|c|c|c|c|c|}
\hline Plant & $\begin{array}{l}\text { PGPR } \\
\text { inoculant }\end{array}$ & $\begin{array}{l}\text { PGPR } \\
\text { mechanisms } \\
\text { envolved }\end{array}$ & $\begin{array}{l}\text { Plant growth parameter } \\
\text { (measure unit) }\end{array}$ & $\begin{array}{l}\text { Increased plant } \\
\text { parameters }^{\mathbf{a}}(\%)\end{array}$ & $\begin{array}{l}\text { Assay condition } \\
\text { and limitation }\end{array}$ & Reference \\
\hline $\begin{array}{l}\text { Sweet cherry } \\
\text { cv. } 0900 \\
\text { Ziraat (Prunus } \\
\text { avium L.) }\end{array}$ & $\begin{array}{l}\text { Pseudomonas } \\
\text { BA-8 and } \\
\text { Bacillus OSU- } \\
142\end{array}$ & & $\begin{array}{l}\text { - Yield per trunk cross- } \\
\text { sectional area }\left(\mathrm{kg} \mathrm{cm}^{-2}\right) \\
\text { - Fruit weight (g) } \\
\text { - Fruit diameter (mm) } \\
\text { - Total soluble solid (\%) } \\
\text { - Titretable acidity (\%) } \\
\text { - Shoot length (cm) } \\
\text { - Shoot diameter (mm) }\end{array}$ & $\begin{array}{c}11-22 \\
1-5 \\
0.2-1 \\
1-4 \\
-0.4-3 \\
11-29 \\
-0.5-0.7\end{array}$ & $\begin{array}{l}\text { - Field experiments } \\
\text { - Non commercial } \\
\text { strains }\end{array}$ & $\begin{array}{l}\text { Esitken et } \\
\text { al., } 2006\end{array}$ \\
\hline $\begin{array}{l}\text { Tomato cv Rio } \\
\text { Fuego } \\
\text { (Lycopersicon } \\
\text { esculentum } \\
\text { Mill) }\end{array}$ & $\begin{array}{l}\text { Bacillus } \\
\text { subtilis BEB- } \\
\text { lSbs (BS13). }\end{array}$ & & $\begin{array}{l}\text { - Yield plant }{ }^{-1}(\mathrm{~g}) \\
\text { - Marketable grade yield (\%) } \\
\text { - Weight/fruit (g) } \\
\text { - Length }(\mathrm{cm}) \\
\text { - Diameter }(\mathrm{cm})\end{array}$ & $\begin{array}{c}21-25 \\
6-20 \\
18-29 \\
9-18 \\
4-5\end{array}$ & $\begin{array}{l}\text { - Greenhouse } \\
\text { experiments } \\
\text { - Non commercial } \\
\text { strains } \\
\text { - Not proven at field } \\
\text { level. }\end{array}$ & $\begin{array}{l}\text { Mena- } \\
\text { Violante } \\
\text { and Olalde- } \\
\text { Portugal, } \\
2007\end{array}$ \\
\hline $\begin{array}{l}\text { Tomato cv } \\
\text { Mairoku (L. } \\
\text { esculentum } \\
\text { Mill.) }\end{array}$ & $\begin{array}{l}\text { Azospirillum } \\
\text { brasilense } \\
\text { CW903, } \\
\text { Burkholderia } \\
\text { pyrrocinia } \\
\text { CBPB-HOD, } \\
\text { Methylobacteriu } \\
\text { m oryzae } \\
\text { CBMB20 } \\
\end{array}$ & $\begin{array}{l}\text { IAA } \\
\text { production, } \\
\text { P solubilizing } \\
\text { and N fixing }\end{array}$ & $\begin{array}{l}\text { - Shoot length }(\mathrm{cm}) \\
\text { - Root length }(\mathrm{cm}) \\
\text { - Stem girth (mm) }\end{array}$ & $\begin{array}{l}8-13 \\
1-13 \\
5-11\end{array}$ & $\begin{array}{l}\text { - Greenhouse } \\
\text { experiment } \\
\text { - Non commercial } \\
\text { strains } \\
\text { - Not proven at field } \\
\text { level. }\end{array}$ & $\begin{array}{l}\text { Madhaiyan } \\
\text { et al., } 2010\end{array}$ \\
\hline
\end{tabular}

${ }^{a}$ Percentage increase over non-inoculated control 
of time in storage, and cost for delivery and incorporation of inoculants into the field. So far, the most commercially successful inoculants have been gram positive spore forming bacteria, which can persist in storage from months to years, and that can withstand starvation, temperature, moisture and other environmental stresses better than nonspore forming bacteria.

Methods for inoculation with either gram negative or gram positive PGPR bacteria require the use of a carrier to deliver the inoculum into the soil and allow mixing of the cells in the soil profile. This can involve low cost carriers such as peat, calcined clay, or powdered corn cobs that are mixed with the bacterial suspensions and dried. Alginate microbeads are also used and provide many advantages by incorporating the cells into a protected matrix that undergoes decomposition in the soil and slowly releases the bacteria. Lastly, bacteria can be introduced into the irrigation water via on-site fermentation equipment that automatically cultures the bacteria and pumps them into the irrigation water at desired intervals. While not widely used, studies employing this technology have shown that it is possible to maintain effective cell densities of pseudomonads in a citrus orchard for control of root rot caused by Phytophthora cinammomi (Steddom et al., 2002) over the whole year. Equipment for irrigation based inoculum delivery continues to improve and provides an innovative method for assuring high cell densities of PGPR, with particular advantages for allowing utilization of gram negative bacteria as soil inoculants.

PGPR population densities are typically much higher in the plant rhizosphere than in the bulk soil. However, correlating population density to activity is a great challenge. The rhizosphere is very heterogenous with respect to nutrient availability. Mature roots are typically colonized by bacteria at densities of $10^{8}$ to $10^{9} \mathrm{CFU} \mathrm{g}^{-1}$ in the mature root zones. However, there is PGPR used for biocontrol of root disease must be active in the same location as the pathogen.

A number of approaches are commonly used to quantify PGPR, including measurements of cell densities based on 16S rRNA gene copy numbers or plating on agar and CFU enumeration. Other approaches employ PCR methods to quantify the copy number of a particular functional gene, or expression of relevant mRNA for genes encoding PGPR traits. A common problem in much research on PGPR has been the failure to monitor the cell density of the introduced bacteria over time to confirm that inoculation was effective. In such cases, it is not possible to determine whether PGPR are responsible for the observed effects or to explain variations in efficacy of the inoculants that may be caused by management or environmental factors.

Mathematical modeling of the behavior of PGPR soil inoculants has been used to predict how various environmental factors affect the survival and activity of PGPR soil inoculants (Strigul and Kravchenko, 2006). Supporting much experimental work, the model by Strigul and Kravchenko illustrates that survival and growth of newly introduced bacteria are strongly limited by competition for organic substrates with the resident microflora. PGPR are predicted to be the most effective in soils with low organic matter or stressed soils where growth of the indigenous population is restricted. In the case of disease suppressive pseudomonads that produce the antibiotic 2,4-diacetylphloroglucinol (2,4-DAPG), the effective population size to obtain suppression of take-all decline of wheat caused by Gaeumannomyces graminis is 
in the range of $10^{5}$ to $10^{6} \mathrm{CFU}$ gram soil ${ }^{-1}$. Effective isolates with good rhizosphere competence can be added to the soil at $10^{4}$ CFU and will grow to densities of at least

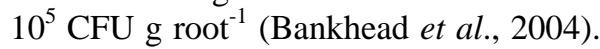
Interestingly, disease suppression effects occur at this threshold cell density and are not enhanced at higher cell densities (Raaijmakers and Weller, 1998). This suggests that once a critical cell mass has been achieved, there is a quorum mediated signal that results in expression of antibiotic production at concentrations that provide the biocontrol.

To date, there is very limited knowledge of how specific inoculants interact with resident microbial populations (Haas and Keel, 2003). Nonetheless, many resident bacteria, possibly including nonculturable bacteria, will carry genes encoding common PGPR functions. In the case of quorum regulated genes, such as those for antibiotic and siderophore production, there is a broad intra and interspecific communication level between different bacterial populations. Thus, it may result in either positive and negative feedback on quorum sensor mediated behavior (Pierson et al., 1998). Prior experiments examining the effects of wheat inoculation with 2,4DAPG producing pseudomonads have shown that there are broad interaction levels not only with various genotypes of resident fluorescent pseudomonads, but with populations of diverse bacterial species including Arthrobacter, Chyrseobacterium, Flavobacteria, and other species that are significantly enriched in the presence of 2,4-DAPG producers (Landa et al., 2003). Similarly, a recent study by Roesti et al. (2006) showed striking shifts in rhizobacterial community structures following inoculation with various combinations of PGPR pseudomonads. However, such interactions are variable and even strain specific for different inoculants. In a study comparing three pseudomonads, relatively minimal changes in community structure of the rhizosphere occurred on wheat grown over multiple cycles (Bankhead et al., 2004), but each inoculant shifted the community in a distinct manner. A larger question is whether inoculation can result in shifts in community structure that increase plant growth promotion and disease suppression functions of the resident community. This question will only be answered once molecular tools are available to detect and quantify all the PGPR relevant phenotypes in the microbial community. As most bacteria in the rhizosphere are still uncultured, this will require a metagenomics approach to identify the genes. Quantitative PCR arrays or DNA microarrays will also provide valuable tools for examining the response patterns of microbial communities to soil inoculants.

\section{Potential marker genes for PGPR monitoring at field level}

Potential marker genes for PGPR functions include those encoding enzymes for antibiotic production, hydrogen cyanide, ethylene destruction and auxin promotion. HCN genes are broadly distributed among many 2,4-DAPG producing pseudomonad strains (Haas and Défago, 2005). PCR primers for a conserved sequence in the $h c n A B$ genes have been shown to be specific for detection of HCN producing pseudomonads from a world-wide collection of isolates (Svercel et al., 2007). Similarly, primers are available to target production of 2,4-DAPG (BergsmaVlami et al., 2005). Typically these primers have been used to test isolates that are cultivated from soil, but can be used with soil with the caveat that gene products that are produced. The PCR products should be further analyzed by 
DNA melting and size check (570 bp fragment) and sequencing to determine the primers have not amplified other genes. An advantage with these primers is that the forward primer can be combined with a GC clamp for analysis of the PCR products by DGGE to assess the genotypic diversity of indigenous DAPGproducing Pseudomonas isolates.

Another target gene for quantification is the accA gene that encodes aminocyclopropane carboxylic acid deaminase. The accA gene is broadly distributed among a wide range of Gram negative bacteria including PGPR pseudomonads, and is common in many Gram-positive bacteria, rhizobia, and fungi (see review: Glick, 2007). Here again, caution must be used during interpretation of changes in accA gene copy numbers, as some bacteria have sequences that are highly similar, but they code instead for enzymes with other functions such as serine deamination. Using PCR methods to detect and quantify PGPR target genes in fallow soils, our experience has been that cell numbers of PGPR and copy numbers of PGPR relevant genes may fall below detection limits, such that the populations are better estimated by culture of a host plant in the soil and baiting of the populations on to the roots where they can readily be quantified in their working habitat.

\section{CONCLUDING REMARKS AND FUTURE TRENDS}

The use of PGPR inoculants to improve agricultural production has been demonstrated in numerous studies and the basic mechanisms are now well understood. PGPR, in accordance with their mode of action, can be classified as biofertilizers, phytostimulators and biopesticides, with certain bacteria having overlapping applications. It is becoming increasingly apparent that most PGPR can promote plant growth by several mechanisms, but most studies currently focus on individual mechanisms and have not been able yet to sort out the relative contributions of different processes that are responsible for plant growth promotion. Screening strategies for selecting the best strains will require more comprehensive knowledge of the traits required for rhizosphere competence, and studies on the ecology of introduced PGPR with the resident PGPR and other microbial species in the plant rhizosphere. While inoculation is now viewed as a means to enhance plant growth, the effects of various management practices or soil amendments on PGPR activity of indigenous bacteria remain unknown. The use of PGPR inoculants in agriculture is already proceeding, and offers many opportunities to improve plant nutrition, crop yields, and disease management, while improving sustainability by reducing the need for chemical inputs. Nevertheless, as our understanding of the ecology of these bacteria improves, it should be possible to obtain a more informed explanation of the mechanisms that are involved in plant growth promotion and identify situations in which bioaugmentation with soil inoculants may be useful for increasing crop yields.

\section{ACKNOWLEDGEMENTS}

The authors are grateful for financial support from FONDECYT Regular Research Project No. 1100625 and FONDECYT Initiation Research Project No. 11080159. O. Martínez-Viveros acknowledges Ph.D. scholarships No.21070354 from CONICYT. D.E. Crowley gratefully acknowledges support from BARD Project No. US 4264-09. 


\section{REFERENCES}

Adesemoye, A.O., Kloepper, J.W. 2009. Plantmicrobes interactions in enhanced fertilizer-use efficiency. Appl Microbiol Biotechnol 85, 1-12.

Ahmad, F., Ahmad, I., Khan, M.S. 2008. Screening of free-living rhizospheric bacteria for their multiple plant growth promoting activities. Microbiol. Res. 163, 173-181.

Alström, S., Burns, R.G. 1989. Cyanide production by rhizobacteria as a possible mechanism of plant growth inhibition. Biol. Fertil. Soils 7, 232-238.

Antoun, H., Beauchamp, C.J., Goussard, N., Chabot, R., Lalande, R. 1998. Potential of Rhizobium and Bradyrhizobium species as plant growth promoting rhizobacteria on non-legumes: Effect on radishes (Raphanus sativus L.). Plant Soil 204, 57-67.

Avis, T.J., Gravel, V., Antoun, H., Tweddell, R.J. 2008. Multifaceted beneficial effects of rhizosphere microorganisms on plant health and productivity. Soil Biol. Biochem. 40, 17331740 .

Bakker, A.W., Schippers, B. 1987. Microbial cyanide production in the rhizosphere in relation to potato yield reduction and Pseudomonas spp. mediated plant growth stimulation. Soil Biol. Biochem. 19, 249-256.

Bankhead, S.B., Landa, B.B., Lutton, E., Weller, D.M., McSpadden Gardener, B.B. 2004. Minimal changes in rhizobacterial population structure following root colonization by wild type and transgenic biocontrol strains. FEMS Microbiol. Ecol. 49, 307-318.

Bashan, Y., de-Bashan, L.E. 2010. How the plant growth-promoting bacterium Azospirillum promotes plant growth-a critical assessment. Adv. Agron. 108, 77-136.

Bashan, Y., Levanony, H. 1990. Current status of Azospirillum inoculation technology: Azospirillum as a challenge for agriculture. Can. J. Microbiol. 36, 591-608.

Bashan, Y., Singh, M., Levanony, H. 1989. Contribution of Azospirillum brasilense Cd to growth of tomato seedlings is not through nitrogen fixation. Can. J. Bot. 67, 2429-2434.
Beattie, G.A. 2006. Plant-associated bacteria: survey, molecular phylogeny, genomics and recent advances. In: S.S. Gnanamanickam (ed).Plant-Associated Bacteria. Springer, Netherlands, pp: 1-56.

Bergsma-Vlami, M., Prins, M.E., Staats, M., Raaijmakers, J.M. 2005. Assessment of genotypic diversity of antibiotic-producing Pseudomonas species in the rhizosphere by denaturing gradient gel electrophoresis. Appl. Environ. Microb. 71, 993-1003.

Bhattacharjee, R.B., Singh, A. Mukhopadhyay, S.N. 2008. Use of nitrogenfixing bacteria as biofertilizer for non-legumes: propects and challenges. Appl. Microbiol. Biot. 80, 199-209.

Blumer, C., Haas, D. 2000. Mechanism, regulation, and ecological role of bacterial cyanide biosynthesis. Arch. Microbiol. 173, 170177.

Boopathi, E., Rao, K.S. 1999. A siderophore from Pseudomonas putida type A1: structural and biological characterization. BBA-Protein Struct. M. $1435,30-40$.

Borie, F., Zunino, H., Martínez, L. 1989. Macromolecule P-associations and inositol phosphates in sole Chilean volcanic soils of temperate regions. Comm. Soil Sci. Plant Anal. 20, 1881-1894.

Bottini, R., Cassán, F., Piccoli, P. 2004. Gibberellin production by bacteria and its involvement in plant growth promotion and yield increase. Appl. Microbiol. Biot. 65, 497-503.

Bottomley, P.J., Myrold, D.D. 2007. Biological N Inputs. In: E. Paul (ed). Soil Microbiology, Ecology and Biochemistry. Academic Press, Oxford, pp: 365-387.

Bowen, G.D., Rovira, A.D. 1999. The rhizosphere and its management to improve plant growth. Adv. Agron. 66, 1-102.

Carrillo-Castañeda, G., Juárez Muños, J., Peralta-Videa, J.R., Gomez, E., Tiemann, K.J., Duarte-Gardea, M., Gardea-Torresdey, J.L. 2002. Alfalfa growth promotion by bacteria grown under iron limiting conditions. Adv. Environ. Res. 6, 391-399.

Chandler, D., Davidson, G., Grant, W.P., Greaves, J., Tatchell, G.M. 2008. Microbial biopesticides for integrated crop management: an 
assessment of environmental and regulatory sustainability. Trends Food Sci. Tech. 19, 275283.

Chen, H., Qualls, R.G., Miller, G.C. 2002. Adaptive responses of Lepidium latifolium to soil flooding: biomass allocation, adventitious rooting, aerenchyma formation and ethylene production. Environ. Exp. Bot. 48, 119-128.

Chen, Y.P., Rekha, P.D., Arun, A.B., Shen, F.T., Lai, W-A., Young, C.C. 2006. Phosphate solubilizing bacteria from subtropical soil and their tricalcium phosphate solubilizing abilities. Appl. Soil Ecol. 34, 33-41.

Chung, H., Park, M., Madhaiyan, M., Seshadri, S., Song, J., Cho, H., Sa, T. 2005 Isolation and characterization of phosphate solubilizing bacteria from the rhizosphere of crop plants of Korea. Soil Biol. Biochem. 37, 1970 1974.

Costacurta, A., Vanderleyden, J. 1995. Synthesis of phytohormones by plant-associated bacteria. Crit. Rev. Microbiol. 21, 1-18.

Cronin, D., Moënne-Loccoz, Y., Fenton, A., Dunne, C., Dowling, D.N., O'gara, F. 1997. Role of 2,4-Diacetylphloroglucinol in the interactions of the biocontrol Pseudomonad strain F113 with the potato cyst nematode Globodera rostochiensis. Appl. Environ. Microb. 63, 13571361.

Crowley, D.E. 2006. Microbial siderophores in the plant rhizosphere. In: L.L. Barton, J. Abadía (eds). Iron Nutrition in Plants and Rhizospheric Microorganisms.Springer, Netherlands, pp: 169198.

Crowley, D.E., Gries, D. 1994. Modeling of iron availability in the plant rhizosphere. In: J.A. Manthey, D.E. Crowley, D.G. Luster (eds). Biochemistry of metal micronutrients in the rhizosphere. Lewis Publishers, Boca Raton, Florida, pp: 199-224.

de Freitas, J.R., Banerjee, M.R., Germida, J.J. 1997. Phosphate-solubilizing rhizobacteria enhance the growth and yield but not phosphorus uptake of canola (Brassica napus L.). Biol. Fertil. Soils 24, 358-364.

Devi, K.K., Seth, N., Kothamasi, S., Kothamasi, D. 2007. Hydrogen cyanideproducing rhizobacteria kill subterranean termite Odontotermes obesus (Rambur) by cyanide poisoning under in Vitro Conditions. Curr. Microbiol. 54, 74-78.

Dobbelaere, S., Croonenborghs, A., Thys, A., Vande Broek, A.,Vanderleyden, J. 1999. Phytostimulatory effect of Azospirillum brasilense wild type and mutant strains altered in IAA production on wheat. Plant Soil 212, 155164.

Dobbelaere, S., Vanderleyden, J., Okon, Y. 2003. Plant growth-promoting effects of diazotrophs in the rhizosphere. Crit. Rev. Plant Sci. 22, 107-149.

Duan, J., Müller, K.M., Charles, T.C., Vesely, S., Glick, B.R. 2009. 1-Aminocyclopropane-1carboxylate (ACC) deaminase genes in rhizobia from Southern Saskatchewan. Microb. Ecol. 57, 423-436.

Esitken, A., Pirlak, L., Turan, M., Sahin, F. 2006. Effects of floral and foliar application of plant growth promoting rhizobacteria (PGPR) on yield, growth and nutrition of sweet cherry. Sci. Hortic-Amsterdam 110:324-327.

Estrada de los Santos, P., Bustillos-Cristales, M.R., Caballero-Mellado, J. 2001. Burkholderia, a genus rich in plant-associated nitrogen fixers with wide environmental and geographic distribution. Appl. Environ. Microb. 67, 2790-2798.

Fernando, W.G.D., Nakkeeran, S., Zhang, Y. 2006. Biosynthesis of antibiotics by PGPR and its relation in biocontrol of plant diseases. In: Z.A. Siddiqui (ed).PGPR: Biocontrol and Biofertilization. Springer, Netherlands, pp: 67109.

Fischer, S.E., Fischer, S.I., Magris, S., Mori, G.B. 2007. Isolation and characterization of bacteria from the rhizosphere of wheat. World J. Microb. Biot. 23, 895-903.

Fuentes-Ramírez, L.E., Caballero-Mellado, J. 2006. Bacterial biofertilizers. In: Z.A. Siddiqui (ed). PGPR: Biocontrol and Biofertilization. Springer, Netherlands, pp: 143-172.

Fuentes-Ramírez, L.E., Bustillos-Cristales, R., Tapia-Hernández, A., Jiménez-Salgado, T., Wang, E.T., Martínez-Romero, E., CaballeroMellado, J. 2001. Novel nitrogen-fixing acetic acid bacteria, Gluconacetobacter johannae sp. nov., and Gluconacetobacter azotocaptans sp. nov., associated with coffee plants. Int. J. Syst. Evol. Micr. 51, 1305-1314. 
Ghosh, S., Penterman, J.N., Little, R.D., Chavez, R., Glick, B.R. 2003. Three newly isolated plant growth-promoting bacilli facilitate the seedling growth of canola, Brassica campestris. Plant Physiol. Bioch. 41, 277-281.

Ghosh, S., Sengupta, C., Maiti, T.K., Basu, P.S. 2008. Production of 3 -indolylacetic acid in root nodules and culture by a Rhizobium species isolated from root nodules of the leguminous pulse Phaseolus mungo. Folia Microbiol. 53, 351-355.

Glick, B.R., Penrose ,D., Li, J. 1998. A model for the lowering of plant ethylene concentrations by plant growth-promoting bacteria. J. Theor. Biol. 190, 63-68.

Glick, B.R., Todorovic, B., Czarny, J., Cheng, Z., Duan, J., McConkey, B. 2007. Promotion of plant growth by bacterial ACC deaminase. Crit. Rev. Plant. Sci. 26, 227-242.

Goldstein, A.H., Krishnaraj, P.U. 2007. Phosphate solubilizing microorganisms vs. phosphate mobilizing microorganisms: What separates a phenotype from a trait? In: E. Velázquez, C. Rodríguez-Barrueco (eds). First International Meeting on Microbial Phosphate Solubilization. Springer, pp: 203-213.

Govindasamy, V., Senthilkumar, M., Gaikwad, K., Annapurna, K. 2008. Isolation and characterization of ACC deaminase gene from two plant growth-promoting rhizobacteria. Curr. Microbiol. 57, 312-317.

Gray, E.J., Smith, D.L. 2005. Intracellular and extracellular PGPR: commonalities and distinctions in the plant-bacterium signaling processes. Soil Biol. Biochem. 37, 395-412.

Grichko, V.P., Glick, B.R. 2001. Amelioration of flooding stress by ACC deaminase-containing plant growth-promoting bacteria. Plant Physiol. Bioch. 39,11-17.

Gyaneshwar, P., Parekh, L.J., Archana, G., Poole, P.S., Collins, M.D., Hutson, R.A., Kumar, G.N. 1999. Involvement of a phosphatestarvation inducible glucose dehydrogenase in soil phosphate solubilization by Enterobacter asburiae. FEMS Microbiol. Lett. 171, 223229.

Haas, D., Défago, G. 2005. Biological control of soil-borne pathogens by fluorescent pseudomonads. Nat. Rev. Microbiol. 3, 307319.
Haas, D., Keel, C. 2003. Regulation of antibiotic production in root-colonizing Pseudomonas spp. and relevance for biological control of plant disease. Annu. Rev. Phytopathol. 41, 117-153.

Halda-Alija, L. 2003. Identification of indole-3acetic acid producing freshwater wetland rhizosphere bacteria associated with Juncus effusus L. Can. J. Microbiol. 49, 781-787.

Hariprasad, P., Niranjana, S.R. 2009. Isolation and characterization of phosphate solubilizing rhizobacteria to improve plant health of tomato. Plant Soil 316, 13-24.

Hernández-Rodríguez A, Heydrich-Pérez $M$, Acebo-Guerrero Y, Velázquez-del Valle MG, Hernández-Lauzardo AN. 2008. Antagonistic activity of Cuban native rhizobacteria against Fusarium verticillioides (Sacc.) Nirenb. in maize (Zea mays L.). Appl. Soil. Ecol. 36, 184-186.

Hussin, A.S.M., Farouk, A-E., Greiner, R., Salleh, H.M., Ismail, A.F. 2007. Phytatedegrading enzyme production by bacteria isolated from Malaysian soil. World J. Microb. Biot. 23, 1653-1660.

Idris, A., Labuschagne, N.,Korsten, L. 2009. Efficacy of rhizobacteria for growth promotion in sorghum under greenhouse conditions and selected modes of action studies. J. Agr. Sci. 147, 17-30.

Jha, B.K., Pragash, M.G., Cletus, J, Raman, G., Sakthivel, N. 2009. Simultaneous phosphate solubilization potential and antifungal activity of new fluorescent pseudomonad strains, Pseudomonas aeruginosa, $P$. plecoglossicida and P. Mosselii. World J. Microb. Biot. 25, 573-581.

Jorquera, M.A., Hernández, M.T., Rengel, Z., Marschner, P., Mora M.L. 2008a. Isolation of culturable phosphobacteria with both phytatemineralization and phosphate-solubilization activity from the rhizosphere of plants grown in a volcanic soil. Biol. Fertil. Soils 44, 1025-1034.

Jorquera, M., Martínez, O., Maruyama, F. Marschner, P., Mora, M.L. 2008b. Current and future biotechnological applications of bacterial phytases and phytase-producing bacteria. Microbes Environ. 23, 182-191.

Karlidag, H., Esitken, A., Turan, M., Sahin, F. 2007. Effects of root inoculation of plant growth promoting rhizobacteria (PGPR) on yield, growth and nutrient element contents of leaves of apple. Sci. Hortic-Amsterdam 114, 16-20. 
Khandelwal, S.R., Manwar, A.V., Chaudhari, B.L., Chincholkar, S.B. 2002. Siderophoregenic bradyrhizobia boost yield of soybean. Appl. Biochem. Biot. 102-103, 155-168.

Kuffner, M., Puschenreiter, M., Wieshammer, G., Gorfer, M., Sessitsch, A. 2008. Rhizosphere bacteria affect growth and metal uptake of heavy metal accumulating willows. Plant Soil 304, 3544.

Kumar, K.V., Singh, N., Behl, H.M., Srivastava, S. 2008. Influence of plant growth promoting bacteria and its mutant on heavy metal toxicity in Brassica juncea grown in fly ash amended soil. Chemosphere 72, 678-683.

Lambert, B., Joos, J. 1989. Fundamental aspects of rhizobacterial plant growth promotion research. Trends Biotechnol. 7, 215-219.

Landa, B.B., Mavrodi, D.M., Thomashow, L.S., and Weller, D.M. 2003. Interactions between strains of 2,4-diacetylphloroglucinolproducing Pseudomonas fluorescens in the rhizosphere of wheat. Phytopathology 93, 982994.

Li, Q., Saleh-Lakha, S., Glick, B.R. 2005. The effect of native and ACC deaminase-containing Azospirillum brasilense Cd1843 on the rooting of carnation cuttings. Can. J. Microbiol. 51, 511514.

Li, J., Shah, S., Moffatt, B.A., Glick, B.R. 2001. Isolation and characterization of an unusual 1-aminocyclopropane-1-carboxylic acid (ACC) deaminase gene from Enterobacter cloacae UW4. Anton. Leeuw. 80, 255-261.

Lim, B.L., Yeung, P., Cheng, C., Hill, J.E. 2007. Distribution and diversity of phytatemineralizing bacteria. ISME J. 1, 321-330.

Loper, J.E., Gross, H. 2007. Genomic analysis of antifungal metabolite production by Pseudomonas fluorescens Pf-5. Eur. J. Plant Pathol. 119, 265-278.

Lugtenberg, B.J.J., Chin-A-Woeng, T.F.C., Bloemberg, G.V. 2002. Microbe-plant interactions: principles and mechanisms. Anton. Leeuw. 81, 373-383.

Lugtenberg, B., Kamilova, F. 2009. Plantgrowth-promoting rhizobacteria. Annu. Rev. Microbiol. 63, 541-556.

Madhaiyan, M., Poonguzhali, S., Kang, B-G., Lee, Y-J., Chung, J-B., Sa, T-M. 2010. Effect of co-inoculation of methylotrophic Methylobacterium oryzae with Azospirillum brasilense and Burkholderia pyrrocinia on the growth and nutrient uptake of tomato, red pepper and rice. Plant Soil 328, 71-82.

Malhotra, M., Srivastava, S. 2008. An ipdC gene knock-out of Azospirillum brasilense strain SM and its implications on indole-3-acetic acid biosynthesis and plant growth promotion. Anton. Leeuw. 93, 425-433.

Mayak, S., Tirosh, T., Glick, B.R. 2004. Plant growth-promoting that confer resistance to water stress in tomatoes and peppers. Plant Sci. 166, 525-530.

Mena-Violante, H., Olalde-Portugal V. 2007. Alteration of tomato fruit quality by root inoculation with plant growth-promoting rhizobacteria (PGPR): Bacillus subtilis BEB13bs. Sci. Hortic-Amsterdam 113, 103-106.

Mirza, M.S., Mehnaz, S., Normand, P., Prigent-Combaret, C., Moënne-Loccoz, Y., Bally, R., Malik, K.A. 2006. Molecular characterization and PCR detection of a nitrogenfixing Pseudomonas strain promoting rice growth. Biol. Fertil. Soils 43, 163-170.

Mostajeran, A., Amooaghaie, R., Emtiazi, G. 2007. The participation of the cell wall hydrolytic enzymes in the initial colonization of Azospirillum brasilense on wheat roots. Plant Soil 291, 239-248.

Mullen, M.D. 2005. Phosphorus in soils: biological interactions. In: D. Hillel, C. Rosenzweig, D. Powlson, K. Scow, M. Singer, D. Sparks (eds).Encyclopedia of Soils in the Environment, Vol.3. Academic Press, Elsevier, Ltd, Oxford, pp: 210-215.

Okon, Y., Kapulnik, Y. 1986. Development and function of Azospirillum inoculated roots. Plant Soil 90, 3-16.

Okon, Y., Labandera-Gonzalez, C.A. 1994. Agronomic applications of Azospirillum: an evaluation of 20 years worldwide field inoculation. Soil Biol. Biochem. 26, 1591-1601.

Oliveira, C.A., Alves, V.M.C., Marriel, I.E., Gomes, E.A., Scotti, M.R., Carneiro, N.P., Guimarães, C.T., Schaffert, R.E., Sá, N.M.H. 2009. Phosphate solubilizing microorganisms isolated from rhizosphere of maize cultivated in an oxisol of the Brazilian Cerrado Biome. Soil Biol. Biochem. 41, 1782-1787. 
Orhan, E., Esitken, A., Ercisli, S., Turan, M. Sahin, F. 2006. Effects of plant growth promoting rhizobacteria (PGPR) on yield, growth and nutrient contents in organically growing raspberry. Sci. Hortic-Amsterdam 111, 38-43.

Patten, C.L. Glick, B.R. 2002. Role of pseudomonas putida indoleacetic acid in development of the host plant root system. Appl. Environ.l Microb. 68, 3795-3801.

Peoples, M., Giller, D., Herridge, D.F., Vessey, K. 2002. Limitations to biological nitrogen fixation as a renewable source of nitrogen for agriculture. In: T. Finan, M. O’Brian, D. Layzell, K. Vessey, W. Newton (eds). Nitrogen Fixation Global Perspectives. CAB International, Wallingford, pp: 356-360.

Pierson, L.S., Wood, D.W., Pierson, E.A. 1998. Homoserine lactone-mediated gene regulation in plant-associated bacteria. Annu. Rev. Phytopathol. 36, 207-225.

Raaijmakers, J.M., Weller, D.M. 1998. Natural plant protection by 2,4-diacetylphloroglucinol producing Pseudomonas spp. in take-all decline soils. Mol. Plant Microbe Interact. 11, 144-152.

Raaijmakers, J.M., Bonsall, R.F., Weller, D.M. 1999. Effect of population density of Pseudomonas fluorescens on production of 2,4diacetylphloroglucinol in the rhizosphere of wheat. Phytopathology 89, 470-475.

Raaijmakers, J.M., Vlami, M., de Souza, J.T. 2002. Antibiotic production by bacterial biocontrol agents. Anton. Leeuw. 81, 537-547.

Reed, M.L.E., Glick, B.R. 2005. Growth of canola (Brassica napus) in the presence of plant growth-promoting bacteria and either copper or polycyclic aromatic hydrocarbons. Can. J. Microbiol. 51, 1061-1969.

Reinhold-Hurek, B., Hurek, T., Gillis, M., Hoste, B., Vancanneyt, M., Kersters, K., De Ley, J. 1993. Azoarcus gen. nov., nitrogen-fixing Proteobacteria associated with roots of Kallar grass (Leptochloa fusca (L.) Kunth), and description of two species, Azoarcus indigens sp. nov. and Azoarcus communis sp. nov. Int. J. Syst. Bacteriol. 43, 574-584.

Rengel, Z. 2008. Bioavailability of phosphorus and micronutrients in the soil-plant-microbe continuum. J. Soil. Sci. Plant Nutr. 8, 84-91.

Rezzonico, F., Zala, M., Keel, C., Duffy, B., Moënne-Loccoz, Y., Défago, G. 2007. Is the ability of biocontrol fluorescent pseudomonads to produce the antifungal metabolite 2,4diacetylphloroglucinol really synonymous with higher plant protection? New Phytol. 173, 861872.

Richardson, A.E., 2001. Prospects for using soil microorganisms to improve the acquisition of phosphorus by plants. Aust. J. Plant Physiol. 28, 897-906.

Richardson, A.E., Barea, J.M., McNeill, A.M., Prigent-Combaret, C. 2009. Acquisition of phosphorus and nitrogen in the rhizosphere and plant growth promotion by microorganisms. Plant Soil 321, 305-339.

Richardson, A.E., Hadobas, P.A. 1997. Soil isolates of Pseudomonas spp. that utilize inositol phosphates. Can. J. Microbiol. 43, 509-516.

Richardson, A.E., Hadobas, P.A., Hayes, J.E., O'Hara, C.P., Simpson, R.J. 2001. Utilization of phosphorus by pasture plants supplied with myo-inositol hexaphosphate is enhanced by the presence of soil micro-organisms. Plant Soil 229, 47-56.

Rodríguez, H., Fraga, R., González, T., Bashan, Y. 2006. Genetics of phosphate solubilization and its potencial applications for improving plant growth-promoting bacteria. Plant Soil 287, 15-21.

Rodríguez-Díaz, M., Rodelas-Gonzalés, B., Pozo-Clemente, C., Martínez-Toledo, M.V., González-López, J. 2008. A review on the taxonomy and possible screening traits of plant growth promoting rhizobacteria. In: I. Ahmad, J. Pichtel, J., S. Hayat (eds). Plant-Bacteria Interactions: Strategies and Techniques to Promote Plant Growth. Wiley-VCH Verlag GmbH \& Co. KGaA, Weinheim, Germany, pp: 55-80.

Roesti, D., Gaur, R., Johri, B.N., Imfeld, G., Sharma, S., Kawaljeet, K., Aragno, M. 2006. Plant growth stage, fertiliser management and bio-inoculation of arbuscular mycorrhizal fungi and plant growth promoting rhizobacteria affect the rhizobacterial community structure in rain-fed wheat fields. Soil Biol. Biochem. 38, 1111-1120.

Roy, N., Chakrabartty, P.K. 2000. Effect of aluminum on the production of siderophore by Rhizobium sp. (Cicer arietinum). Curr. Microbiol. 41, 5-10.

Rudrappa, T., Splaine, R.E., Biedrzycki, M.L., Bais, H.P. 2008. Cyanogenic pseudomonads influence multitrophic interactions in the 
rhizosphere. PLoS ONE 3(4): e2073. doi:10.1371/journal.pone.0002073.

Schippers, B., Bakker, A.W., Bakker, P.A.H.M., Van Peer, R. 1990. Beneficial and deleterious effects of HCN-producing pseudomonads on rhizosphere interactions. Plant Soil 129, 75-83.

Shaharoona, B., Arshad, M., Zahir, Z.A., Khalid, A. 2006. Performance of Pseudomonas spp. containing ACC-deaminase for improving growth and yield of maize (Zea mays L.) in the presence of nitrogenous fertilizer. Soil Biol. Biochem. 38, 2971-2975.

Sharma, A., Johri, B.N. 2003. Growth promoting influence of siderophore-producing Pseudomonas strains GRP3A and PRS9 in maize (Zea mays L.) under iron limiting conditions. Microbiol. Res. 158, 243-248

Shedova, E., Lipasova, V., Velikodvorskaya, G., Ovadis, M., Chernin, L., Khmel, I. 2008. Phytase activity and its regulation in a rhizospheric strain of Serratia plymuthica. Folia Microbiol. 53, 110-114.

Shoebitz, M., Ribaudo, C.M., Pardo, M.A., Cantore, M.L., Ciampi, L., Curá, J.A. 2009. Plant growth promoting properties of a strain of Enterobacter ludwigii isolated from Lolium perenne rhizosphere. Soil Biol. Biochem. 41, 1768-1774.

Siddiqui, Z.A. 2006. PGPR: Prospective biocontrol agents of plant pathogens. In: Z.A Siddiqui (ed). PGPR: Biocontrol and Biocontrol. Springer, Netherlands, pp: 112-142.

Siddiqui, I.A., Shaukat, S.S., Hussain Sheikh, I., Khan, A. 2006. Role of cyanide production by Pseudomonas fluorescens CHA0 in the suppression of root-knot nematode, Meloidogyne javanica in tomato. World J. Microb. Biot. 22, 641-650.

Somers, E., Vanderleyden, J., Srinivasan, M. 2004. Rhizosphere bacterial signalling: a love parade Veneta our feet. Crit. Rev. Microbiol. 30, 205-240.

Spaepen, S., Dobbelaere, S., Croonenborghs, A., Vanderleyden, J. 2008. Effects of Azospirillum brasilense indole-3-acetic acid production on inoculated wheat plants. Plant Soil $312,15-23$.

Spaepen, S., Vanderleyden, J., Remans, R. 2007. Indole-3-acetic acid inmicrobial and microorganism-plant signaling.

Microbiol. Rev. 31, 425-448.

Steddom, K., Menge, J.A., Crowley, D.E., Borneman, J. 2002. Effect of repetitive applications of the biocontrol bacterium Pseudomonas putida 06909-rif/nal on citrus soil microbial communities. Phytopathology 92, 857862.

Strigul, N.S., Kravchenko, L.V. 2006 Mathematical modeling of PGPR inoculation into the rhizosphere. Environ. Modell. Softw. 21, 1158-1171.

Swain, M.R., Naskar, S.K., Ray, R.C. 2007. Indole-3-acetic acid production and effect on sprouting of Yam (Dioscorea rotundata L.) minisetts by Bacillus subtilis isolated from culturable cowdung microflora. Pol. J. Microbiol. $56,103-110$.

Svercel, M., Duffy, B., Défago, G. 2007. PCR amplification of hydrogen cyanide biosynthetic locus hcnAB in Pseudomonas spp. J. Microbiol. Meth. 70, 209-213.

Tsavkelova, E.A., Cherdyntseva, T.A., Klimova. S.Y., Shestakov, A.I., Botina, S.G., Netrusov, A.I. 2007. Orchid-associated bacteria produce indole-3-acetic acid, promote seed germination, and increase their microbial yield in response to exogenous auxin. Arch. Microbiol. 188, 655-664.

Tsavkelova, E.A., Klimova, S.Y. Cherdyntseva, T.A., Netrusov, A.I. 2006. Microbial producers of plant growth stimulators and their practical use: a review. Appl. Biochem. Micro. 42, 117-126.

Tilak, K.V.B.R., Ranganayaki, N., Pal, K.K., De, R., Saxena, A.K., Nautiyal, C.S., Mittal, S., Tripathi, A.K., Johri, B.N. 2005. Diversity of plant growth and soil health supporting bacteria. Curr. Sci. India 89, 136-150.

Timmusk, S., Nicander, B., Granhall, U., Tillberg, E. 1999. Cytokinin production by Paenibacillus polymyxa. Soil Biol. Biochem. 31, 1847-1852.

Turner, B.L., Papházy, M.J., Haygarth, P.M., McKelvie, I.D., 2002. Inositol phosphates in the environment. Philos. T. Roy. Soc. B 357, 449469.

Unkovich, M., Baldock, J. 2008. Measurement of asymbiotic N2 fixation in Australian agriculture. Soil Biol. Biochem. 40, 2915-2921. 
Unno, Y., Okubo, K., Wasaki, J., Shinano, T., Osaki, M. 2005. Plant growth promotion abilities and microscale bacterial dynamics in the rhizosphere of Lupin analysed by phytate utilization ability. Environ. Microbiol. 7, 396404.

van Loon, L.C. 2007. Plant responses to plant growth-promoting rhizobacteria. Eur. J. Plant Pathol. 119, 243-254.

Vassilev, N., Vassileva, M., Nikolaeva, I. 2006. Simultaneous P-solubilizing and biocontrol activity of microorganisms: potentials and future trends. Appl. Microbiol. Biot. 71, 137-144.

Velusamy, P., Immanuel, J.E., Gnanamanickam, S.S., Thomashow, L. 2006. Biological control of rice bacterial blight by plant-associated bacteria producing 2,4diacetylphloroglucinol. Can. J. Microbiol. 52, 56-65.

Vessey, J.K. 2003. Plant growth promoting rhizobacteria as biofertilizers. Plant Soil 255, 571-586.

Voisard, C., Keel, C., Haas, D., Défago, G. 1989. Cyanide production by Pseudomonas fluorescens helps suppress black root rot of tobacco under gnotobiotic conditions. EMBO J. 8, 351-358.

Wani, P.A., Khan, M.S., Zaidi, A. 2007. Coinoculation of nitrogen-fixing and phosphatesolubilizing bacteria to promote growth, yield and nutrient uptake in chickpea. Acta Agron. Hung. 55, 315-323.
Whipps, J.M. 2001. Microbial interactions and biocontrol in the rhizosphere. J. Exp. Bot. 52, 487-511.

Yao, A. V., Bochow, H., Karimov, S., Boturov, U., Sanginboy, S.,Sharipov, A. K. 2006. Effect of FZB $24 \AA$ Bacillus subtilis as a biofertilizer on cotton yields in field tests. Arch. Phytopathol. Plant Prot. 39, 323 -328.

Yao, T., Yasmin, S., Hafeez,F.Y. 2008 Potential role of rhizobacteria isolated from Northwestern China for enhancing wheat and oat yield. J. Agric. Sci. 146, 49-56

Zahir, A.A., Arshad, M., Frankenberger, W.T. 2004. Plant growth promoting rhizobacteria: applications and perspectives in agriculture. Adv. Agron. 81, 97-168.

Zahir, Z. A., Asghar, H. N., Akhtar, M. J. and Arshad, M. 2005. Precursor (L-tryptophan)inoculum (Azotobacter) interaction for improving yields and nitrogen uptake of maize. J. Plant Nutr. 28, 805-817.

Zahran, H.H. 2001. Rhizobia from wild legumes: diversity, taxonomy, ecology, nitrogen fixation and biotechnology. J. Biotechnol. 91, 143-153

Zehnder, G.W., Murphy, J.F., Sikora, E.J., Kloepper, J.W. 2001. Application of rhizobacteria for induced resistance. Eur. J. Plant Pathol. 107, 39-50. 